UDC 339

\title{
THE EFFECT OF MARKETING MIX FOR E-COMMERCE ON CUSTOMER ONLINE BEHAVIOUR: A STUDY ON LANGUAGE SERVICES PROVIDER
}

\author{
Fakhrurozi Rifqi Nur, Kusumawati Andriani*, Raharjo Kusdi \\ Department of Business Administration, Faculty of Administrative Science, \\ University of Brawijaya, Malang, Indonesia \\ *E-mail: andriani kusuma@ub.ac.id
}

\begin{abstract}
Marketing mix is part of marketing science that can be managed by a company to influence customers' behaviour. This research was aimed to analyze and explain the effect of marketing mix on customer trust, purchase decision, customer satisfaction and behavioural intention. In other words, it was aimed to figure out customers' experience before purchase, during purchase decision making, and after purchase. The research was conducted at Excellent Translation, a company which focused its marketing on online marketing. A total of 145 customers were selected using random sampling technique. SmartPLS was used for data analysis, from which significance level of 0.05 . The results of the research showed that marketing mix had a significant effect on trust and purchase decision, that purchase decision had a significant effect on customer satisfaction, and that customer satisfaction had a significant effect on behavioural intention.
\end{abstract}

\section{KEY WORDS}

Marketing mix, customer trust, purchase decision, customer satisfaction.

In Indonesia, the growth of online-based services company (e-commerce) is affirmed. This is supported by the emergence of various start-up companies such as, GoJek (ojek online services), JNE (freight forwarding), Traveloka (hotel and transport ticket booking services), Trivago (hotel booking service online), and others. With the number of internet users which had reached 89 million people or about $30 \%$ of the total population in Indonesia in 2014, it is no wonder Indonesia becomes the target market of e-commerce foreign investors and new opportunities for the community of Indonesia. This is in line with data from the $\mathrm{MoCl}$ which states that the value of e-commerce transactions in 2014 reached USD 12 billion (kominfo.go.id, 2017). One of service companies that develop in line with the development of e-commerce based company is a translation service company.

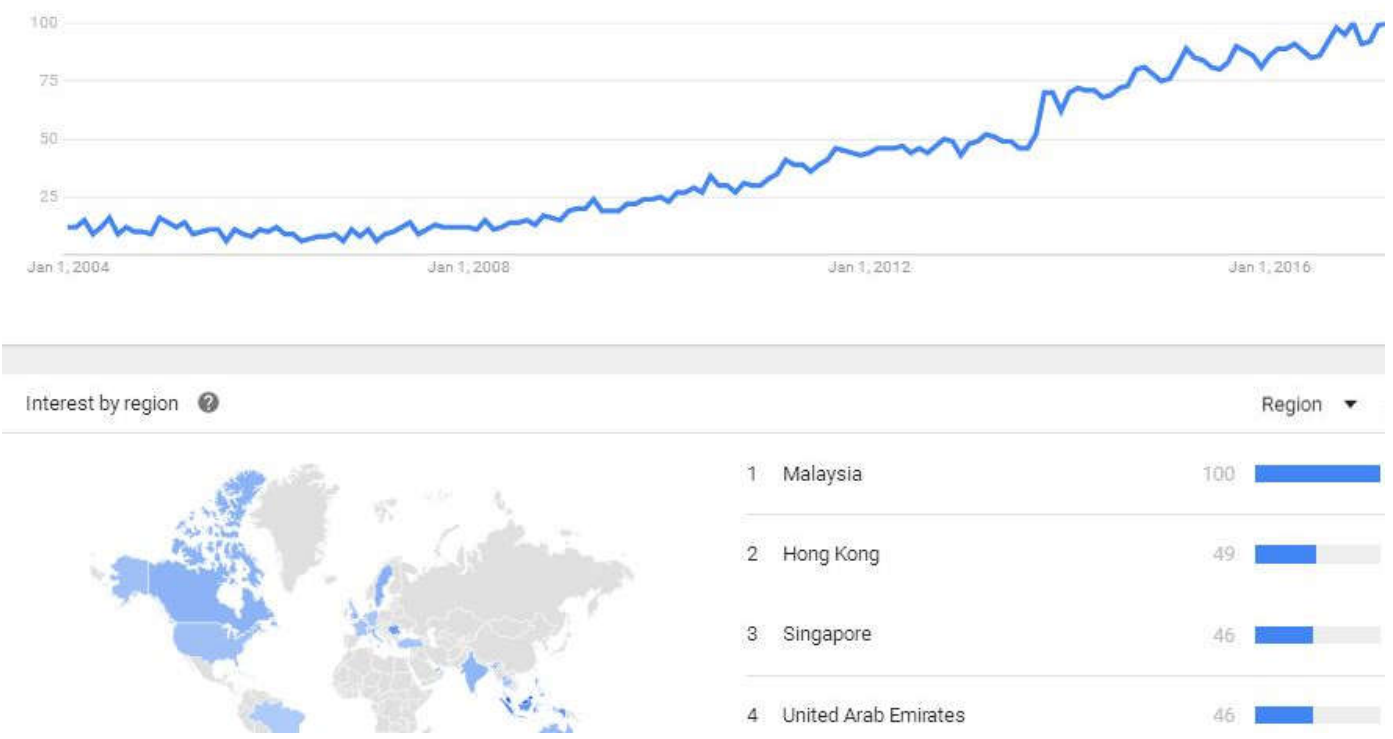

Figure 1 - Google Trand with the keyword "Translation Service" 
It is obvious that a translator company is needed for an e-commerce-based company. In addition to translating documents, various other kinds of products also have the opportunity to require translation services. Such as translator software user interface for mobile or computer, service make article translation for cointain website, AdWord localization for Search Engine Optmation (SEO), until we often enjoy subtitled video.

The need for translator services is in line with data from google trend that shows increased keyword search of "translation service" from 2018 until now (Figure 1). Seeing these opportunities, many translation service companies are growing in Indonesia with only utilize e-commerce website, such as jtc-indonesia.com, gamalingua.com, parapenerjemah.com, solisuipenerjemah.com, and others. One of them is Excellent Translation with the domain of jasa-translate.com at which this research was done. On the other hand, it does not hinder a larger and longer-term Indonesian translation companies standing into the Indonesian market by providing translation services into Indonesian (Common Sense Advisory: Top 100 Language Service Providers by Stephen Henderson 2016).

Given the many opportunities and threats of competitors, Excellent Translation is required to take advantage of these opportunities by increasing purchasing decisions and being able to compete with competitors by maximizing customer satisfaction, as creating value and customer satisfaction will shape positive consumer behavior for the future (Bendall-Lyon and Powers, 2004), while customer satisfaction will be fulfilled when what is expected equivalent with what is obtained after the purchase of services (Hafeez and Hasnu, 2010). In other words, improving purchasing decisions can also increase consumer satisfaction.

Darmasaputra (2015) and Rezky et al (2012) in their research indicate that purchasing decisions are influenced by marketing mix. The purpose of a marketing mix is that the services offered are acceptable to customers or purchased by customers. In addition to the marketing mix, customer confidence in the internet business is the main factor a person to be willing to shop online (Gefen et al, 2003). Because doing business transactions online is threatened with many risks. Gefen and Straub (2004) argue that the lack of rules and regulations governing the Internet, keeps customers from relying on the trust and popularity of an online store to reduce uncertainty and risk.

\section{LITERATURE REVIEW}

The trend of customer behaviour change in the era of Internet technology requires that companies change their business methods following the development of customer behaviour (Kotlyarov, 2012). Marketing mix consists of variables that a company can control in order to achieve its marketing target (Kotler and Amstrong, 2010). Marketing mix elements can be implemented in various businesses and continuously develop and change according to the condition of the company and the market target. Booms and Bitner (1981) introduced the 7Ps of marketing mix for services companies. This was later developed by Kalayanam and Mclntyre (2002), who proposed the 4Ps + P2C2S2 of marketing mix, with an addition of some elements, namely personalization, privacy, customer service, community, security, and site design. This research, however, used the "marketing mix for e-commerce" proposed by Pogorelova et al. (2016). Basically, "marketing mix for e-commerce" adopts the 7Ps of marketing mix and e-marketing mix, where the customer service, community, and site design are incorporated with the components process, promotion, physical evidence, and some other elements that were adjusted to the environmental condition of e-commerce. The following is the explanation of each element:

a. Product, goods or service offerred to customers

b. Price, a monetary unit that must be sacrificed in order to obtain services or goods

c. Promotion, a communication activity to inform and influence customers (social media, email, web-conference, webinar)

d. Place, a virtual selling point such as website, social media, or collective platforms (Tokopedia, OLX, Alibaba, etc.) 

customers

e. People, all actors involved since production until delivery of products or goods to

f. Process, a combination of all activities since production until delivery of products or goods to customers

g. Physical Evidence, physical presentation illustrating a company virtually

There have been a number of studies discussing the effect of marketing mix on trust. Kim et al. (2004) stated that marketing mix has a significant effect on trust. The results of the research showed that trust increases with the increase in product quality and promotion conducted by a company. Another study conducted by Hikmawati et al. (2015) examined the correlation between marketing relationship, marketing mix and trust. The results of the study showed that marketing mix has a significant effect on trust. Morgan and Hunt (1994) stated that trust is a key variable for the success of marketing. Similar to marketing mix, the success of marketing mix applied by a company is evident if the marketing mix is able to build trust in customers in the services/products offerred.

Mowen and Minor (1998) explained that trust is built from customers' knowledge and inference on objects, attributes, and benefits. In this research, object refers to all elements in the 7Ps of marketing mix; attribute refers to the characteristics or features present or absent in an object; and benefit refers to the positive outcome presented by customers. In other words, trust will increase or decrease according to their perception on the marketing mix applied by the company.

$\mathrm{H} 1$ : Marketing mix has a positive and significiant effect on customer trust.

Peter and Olson (2000) stated that purchase decision making is an integration process combining knowledge and information for evaluating various possibilities and selecting one of the possibilities. The information can be in the form of price, product, place, person, etc. Customers rely on the information they gain or suggestions from others (sellers or friends) to help them make a selection. Thus, it is important for a company to optimize the role of marketing mix in order to deliver information and knowledge on the products/services offered and to influence customers' decision (Nowlis, 1995).

Kotler and Amstrong (2012) assumed that too many attributes will make it difficult for customers to make decision. Attributes in this case may be the elements of marketing mix or anything other than the elements of marketing mix and may be derived from one company or more which offers similar products/services. The elements will be evaluated by the customers, and in doing so, the customers will be influenced by the situations, knowledge, motivation, and environment (Engel et al., 1993). Price is an element normally set as a standard when evaluating quality is deemed difficult or when there are unreasonable number of services options (Pinson and Joliber, 1998).

There are some other studies discussing the effect of marketing mix on purchase decision. The study by Hidayati (2016) showed that marketing mix had a significant effect on purchase decision. This study discussed the correlation between marketing mix and purchase decision using the AIDA model as an intervening variable.

$\mathrm{H} 2$ : Marketing mix has a positive and significant effect on purchase decision

Most customers assumes that trust is built by finding out anything related to a seller from his or her reputation or from mutually beneficial policies (Gefen, 2000). From the perspective of the seller, customers' trust is also taken into consideration as he or she must make sure that customers will exercise their obligations. Keen et al. (2000) claimed that a good customer is a key factor to build trust, both online and offline. Moorman et al. (1993) defined trust as customers' willingness to rely on the service/goods provider, in the hope that the service/goods provider will fulfill their need as promised. McKnight et al. (2002a) mentioned two indicators of trust, namely:

- Trusting belief, perceived belief of customers in a service provider that has the characteristics to meet their need;

- Trusting intention, something that is intended, where customers are willing to rely on a service provider in a given situation.

Trust has a crucial role in relationship building, especially in e-commerce-based business in the services sector (Sonja and Edwald, 2003), which has been cited as one of 
reasons customers are reluctant to make a purchase online (Lee and Turban, 2001). Numerous scholars and practitioners acknowledged the relevance between trust and purchase decision. A study conducted in nine European countries by Capgemini ernst \& Young (2000) showed that more than 6,000 customers expressed that online customers put greater importance on trust and reliability of online sellers. Yunus (2006) argued that trust is an "appeal" that invites transaction opportunities. It is arguable that trust constitutes the trust of a certain party in the other in a transaction relationship based on a belief that the trusted party will meet any obligation in an expected satisfactory way. In other words, the higher the trust, the greater the confidence of customers that a company will fulfill their need, which convinces them to decide to use its services/products.

Customer trust has always been considered as the most vital factor as it encourages customers' purchase decision. For instance, the research by Jaravenpaa et al. (2000) showed that trust had a significant effect on purchase decision. Quareshi (2015) in his research discussed the effect of trust on purchase decision by involving MBA (Master of Business Administration) and MCA (Master of Computer Applications) students as the objects. The results showed that trust had a significant effect on purchase decision. This suggested the necessity to increase trust in order to encourage customers' purchase decision. Another study on the effect of trust on online intention was conducted by Beccera and Korgankar (2009). In that research, trust was devided into a number of variables, namely vendor trust, brand trust, and product trust. From that research it could be concluded that the trust in the salesperson, product, company, vendor, brand, and other holds great importance as it can influence customers' purchase intention and is useful for maintaining a long-term relationship between a company and its customers.

H3: Trust has a positive and significant effect on purchase decision.

Research decision according to Kotler and Amstrong (2012) is the decision made by customers after undertaking some processes, starting from information search and evaluation until deciding on one of two or more choices of translating service providers. Mohr (2010) explained several stages of deciding the purchase of technology-based products/services, namely:

- Information search: The search of information regarding products/services of interest to promote positive properties of the products;

- Evaluation: Varied attitude to select and obtain available information and to choose some benefits which are offered;

- Actual Purchase: Final decision to purchase or to use a product/service.

In the process of purchase decision making, customers will not stop in the consumption process but will proceed to the process of evaluation of their experience in using a product/service. As a result of the evaluation, they will feel satisfied or dissatisfied. The initial concept of customer satisfaction is defined as a post-purchase decision evaluative assessment, which later develops into expectation and performance (Oliver, 1980). Johnson et al. (1995) argued that customer satisfaction is a cumulative construct influenced by market expectation and perceived performance in a given period and by satisfaction from time to time (experience). Homburg (2007) stated that customer satisfaction is "an overall postpurchase evaluation". In other words, the perception on experience of using a product is compared with the expectation before using the product. It can be concluded, then, that customer satisfaction can be achieved after the customer decides to purchase a service.

Some researchers seek to conduct further research relating to the emotion evoked during and after the use of a product/service (Bagozzi and Gopinath, 1999; Richins, 1997; Mattila and Enz, 2002). In a previous study, Kautsar et al. (2012) stated that purchase decision has a significant effect on the satisfaction of non-prescription drugs customers. Another study by Lee and Kacen (2008) also discussed the levels of customer satisfaction viewed from how a product is purchased, planned purchase, and impulse purchase by illustrating Western culture as a whole.

$\mathrm{H} 4$ : Purchase decision has a positive and significant effect on customer satisfaction.

Customer satisfaction is highly considered by a company as a key indicator of success and capital for future competition (Anderson and Srinivasan, 2003). Gerson (2001) stated 
that customer satisfaction is what customers feel when their need is fulfilled or exceeded. It is the intention of every company to satisfy customers' need. Not only is it important for the continuity of a company, satisfying the customers' need can also increase the company's advantages in competition. Customers who are satisfied with a product or service tend to repurchase the product or reuse the service when the need arises in the future. According to Hafeez and Hasnu (2010), there are several indicators used in the customer satisfaction concept, namely:

- Fullfillment of expectation, if a company is able to meet customers' expectation;

- Overall satisfaction, which shows the extent to which customers are satisfied with all processes, starting from pre-purchase until post-purchase.

\section{METHODS OF RESEARCH}

Sampling and Data Method:

Table 1 - Demographic characteristics of respondents

\begin{tabular}{lll}
\hline Profile & Characteristics & $\%$ \\
\hline Gender & Male & $52 \%$ \\
Age & Female & $47 \%$ \\
& $<20$ years old & $4.14 \%$ \\
& $20-29$ years old & $48.28 \%$ \\
& $30-39$ years old & $33.79 \%$ \\
Education & $40-49$ years old & $11.03 \%$ \\
& $>50$ years old & $2.76 \%$ \\
& Senior high school & $9.66 \%$ \\
Profession & Diploma & $4.14 \%$ \\
& Bachelor's degree & $63.45 \%$ \\
& Master's degree & $22.76 \%$ \\
& Freelancers & $4.14 \%$ \\
& civil servants & $6.21 \%$ \\
& Lecturers & $8.97 \%$ \\
& Students & $20 \%$ \\
& Private employees & $49.66 \%$ \\
\end{tabular}

The sample consisted of a total of 145 respondents, the data from which were analyzed, see table 1 for description. A previous study in the field of online shopping claimed that self-administered online survey is the most appropriate method to collect data (Chen and Barnes, 2007). The population of this research consisted of Excellent Translation's customers. Samples of 145 people were obtained with random sampling technique, which was inclusive of error tolerance limit of $7 \%$. The data used in this research were primary data. Primary data were obtained directly from the respondents' answers to a questionnaire sent by email. The email contained a link to a provided Google Form. The Questionnaire was devided into two parts, namely descriptive information or customers' demography (gender, age, education, and profession) and customers' statements regarding the research variables

Measurments. This research examined 4 construct, namely marketing mix, customer trust, purchase decision and customer satisfaction. Each variable consisted of a number of indicators, and some indicators had a number of items. Marketing mix consisted of product, price, promotion, place, people, process, physical evidence (Pogorelova et al., 2016). Trust consisted of trusting belief and trusting intention (McKnight et al., 2002a). Purchase decision consisted of information search, evaluation, and actual purchase (Mohr, 2010). Customer satisfaction consisted of expectation and overall satisfaction (Hafeez and Hasnu, 2010). The entire indicators were measured through several items built based on previous studies which had been validated. Likert Scale from negative extreme to positive extreme (a scale of 1-5), where a scale of 1 denotes disagreement and a scale of 5 denotes extreme agreement, was used. These indicators were chosen as they fitted with the field of present research, which adopted e-commerce, and the items used were more flexible and adjustable to the research object. 


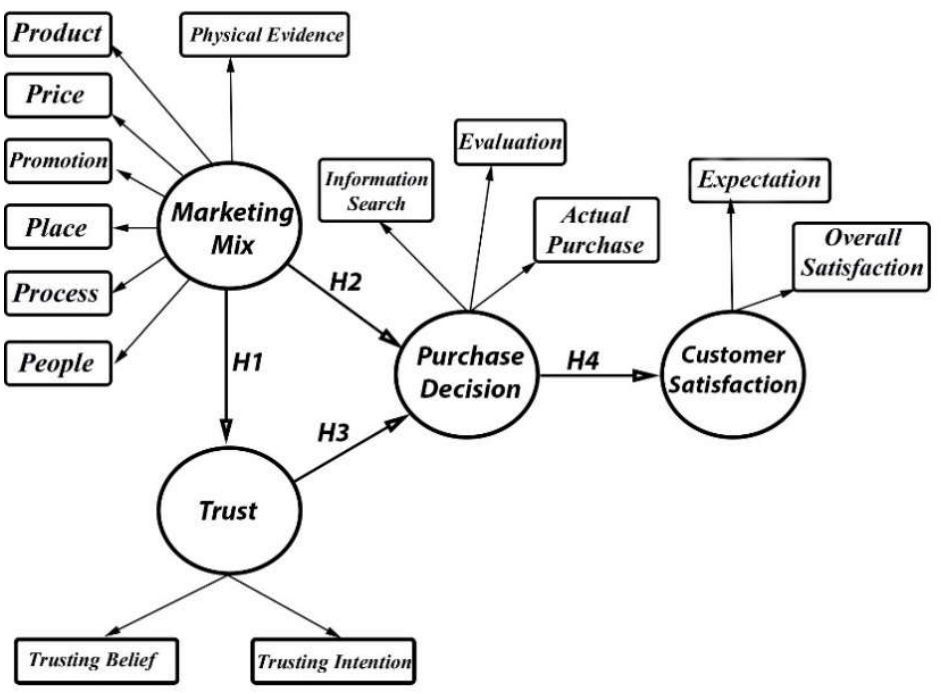

Figure 2 - Theoretical proposed model

PLS-SEM analysis method. PLS path models are formally defined by two sets of linear equations: the measurement model (also called outer model) and the structural model (also called inner model). The measurement model specifies the relations between a construct and its observed indicators (also called manifest variables), whereas the structural model specifies the relationships between the construct. The structural model consists of exogenous and endogenous constructs as well as the relationships between them. The values of exogenous constructs are assumed to be given from outside the model. Thus, exogenous variables are not explained by other constructs in the model, and there must not be any arrows in the structural model that point to exogenous constructs. In contrast, endogenous constructs are at least partially explained by other constructs in the model. Each endogenous construct must have at least one arrow of the structural model pointing to it. The relationships between the constructs are usually assumed to be linear. The size and significance of path relationships are typically the focus of the scientific endeavors pursued in empirical research.

According to Henseler and Chin (2010) and Hair et al. (2013), the first step in SEM analysis is measurement model assessment; next is the structural model results' assessment (the two-stage approach). The focus of measurement model assessment is to evaluate the causal relations between the indicators/items and validation of the theoretical constructs, while the structural model evaluates the causal relations between the theoretical constructs (Anderson and Gerbing 1982). In respect of measurement assessment, construct validity is defined as "the extent to which an operationalization measures the concept it is supposed to measure" (Bagozzi et al, 1991). Further, convergent and discriminant validity are assessed. Convergent validity is defined as "the degree to which multiple attempts to measure the same concept are in agreement," while discriminant validity is defined as "the degree to which measures of different concepts are distinct" (Bagozzi et al. 1991). The structural model assesses R2 measures and the level and significance of the path coefficients ( $\beta$ ) by performing the bootstrapping procedure of 5,000 resamples (Hair et al. 2011). Thus, SmartPLS software (Ringle et al., 2005) is used in this study to assess the PLS-SEM analysis.

\section{RESULTS AND DISCUSSION}

As discussed, to assess the reflective measurement models using PLS-SEM, construct validity, using outer weights or loadings, composite reliability (CR), convergent validity, and discriminant validity were examined. As depicted in Table 2, all the outer loadings of items are well above the threshold of 0.70 , and all constructs have high levels of internal consistency reliability established by the CR values. Secondly, convergent validity was 
evaluated using AVE, for which the results show that all the AVE values are well above the threshold of 0.5 , thereby demonstrating the convergence of the research construct. Figure 2 presents the measurement model including outer loadings along with the $\beta$ and R2 values. Furthermore, all the outer $t$ statistics show that the $t$ value is higher than 2.58 (sig. level at $1 \%)$. From the outer $t$ statistics managers can empirically set "actionable strategies" based on the sizes of the exogenous construct item weights (Hair et al. 2013).

Table 2 - Consturct Validity, Composite Reliability, Cronbach Alpha, Outer T-statistics

\begin{tabular}{|c|c|c|c|c|c|c|}
\hline Construct & Indicator & $\begin{array}{c}\text { Outer } \\
\text { Weights }\end{array}$ & AVEa $^{a}$ & $\begin{array}{l}\text { Composite } \\
\text { Reliabilityb }\end{array}$ & $\begin{array}{c}\text { Cronbachs } \\
\text { Alpha }\end{array}$ & $\begin{array}{l}\text { Outer T- } \\
\text { Statisticc }\end{array}$ \\
\hline \multirow[t]{7}{*}{ MM } & MM1 & 0.820069 & 0.6727 & 0.9349 & 0.9186 & 14.064647 \\
\hline & MM2 & 0.877719 & & & & 27.740571 \\
\hline & MM3 & 0.797565 & & & & 13.150404 \\
\hline & MM4 & 0.750751 & & & & 10.423686 \\
\hline & MM5 & 0.814268 & & & & 12.549290 \\
\hline & MM6 & 0.824088 & & & & 20.693660 \\
\hline & MM7 & 0.851147 & & & & 19.183655 \\
\hline \multirow[t]{2}{*}{ CT } & T1 & 0.935228 & 0.8535 & 0.921 & 0.8292 & 49.553677 \\
\hline & T2 & 0.912363 & & & & 30.873363 \\
\hline \multirow[t]{3}{*}{ PD } & PD1 & 0.894353 & 0.8088 & 0.927 & 0.8829 & 25.777749 \\
\hline & PD2 & 0.918404 & & & & 37.888376 \\
\hline & PD3 & 0.885039 & & & & 30.291262 \\
\hline \multirow[t]{2}{*}{ CS } & CS1 & 0.949777 & 0.9028 & 0.9489 & 0.8924 & 56.069875 \\
\hline & CS2 & 0.950592 & & & & 57.941903 \\
\hline
\end{tabular}

${ }^{a} A V E=$ (summation of the square of the factor loadings) $/\{($ summation of the square of the factor loadings) + (summation of the error variances)\}.

${ }^{b}$ Composite reliability $(C R)=$ (square of the summation of the factor loadings) $/$ (square of the summation of the factor loadings) + (square of the summation of the error variances)\}.

ct values: $t$ value 2.58 (sig. level = 1\%). From the outer $t$ statistics, a set of "actionable strategies" based on the sizes of the exogenous construct indicator weights is interpreted.

${ } \mathrm{MM}=$ Marketing Mix; $C T=$ Customer Trust; $P D=$ Purchase Decision; $C S$ = Customer Satisfaction; $B I=$ Behavioral Intention

eMM1 = Product; $M M 2$ = Price; $M M 3$ = Promotion; MM4 = Place; MM5 = Process; MM6 = People; MM7 = Physical Evidence; CT1 = Trust Belief; CT2 = Trust Intention; PD1 = Information Search; $P D 2$ = Evaluation; $P D 3=$ Actual Purchase $;$ CS1 = Excpectation; $C S 2$ = Overall Satisfaction .

Table 3 - Discriminant validity (Fornell-Larcker criterion)

\begin{tabular}{lllll}
\hline Construct $^{\mathrm{b}}$ & $\mathrm{MM}$ & $\mathrm{CT}$ & $\mathrm{PD}$ & $\mathrm{CS}$ \\
\hline $\mathrm{MM}$ & $\mathbf{0 . 6 7 2 7 \mathrm { a }}$ & & & \\
$\mathrm{T}$ & 0.5857 & $\mathbf{0 . 8 5 3 5}$ & & \\
$\mathrm{PD}$ & 0.4589 & 0.5399 & $\mathbf{0 . 8 0 8 9}$ & $\mathbf{0 . 9 0 2 8}$ \\
$\mathrm{CS}$ & 0.3090 & 0.5161 & 0.7060 & $\mathbf{0 . 9}$ \\
\hline
\end{tabular}

aThe off-diagonal values in the above matrix are the square correlations between the latent constructs, and the diagonal values are AVEs.

${ }^{b} \mathrm{MM}=$ Marketing Mix; $C T=$ Customer Trust $; P D=$ Purchase Decision; $C S=$ Customer Satisfaction .

To assess construct validity, the discriminant validity between the research constructs was assessed using Fornell and Larcker (1981) and cross-loading criterion. As depicted in Table 3, the off-diagonal values are the square correlations between the latent research constructs, and the diagonal values are AVEs. Thus, the Fornell and Larcker criterion shows that discriminant validity between the constructs exists.

Discriminant validity is used to construct latent constructs predicting the size of their blocks. Ghozali (2014) mentions that the discriminant validity of the measurement model with reflexive indicators based on intersections contains measurements with constructs. Discriminative validity of measurement models based on cross-load measurements with constructs. If the constructs with the principal measurements (each indicator) are larger than the other construct size, the latent construct predicts the indicator better than the other construct, as comparing the loadings across the columns in Table 4 implies that an 
indicator's loadings on its own construct are in all cases higher compared to all of its crossloadings with other construct.

Table 4 - Discriminant validity: Loading and cross loading criterionab

\begin{tabular}{lllll}
\hline Indicator $^{d}$ & $\mathrm{MM}$ & $\mathrm{CT}$ & $\mathrm{PD}$ & $\mathrm{CS}$ \\
\hline MM1 & $\mathbf{0 , 8 2 0 0}$ & 0,4961 & 0,2935 & 0,2997 \\
MM2 & $\mathbf{0 , 8 7 7 7}$ & 0,5388 & 0,4848 & 0,3494 \\
MM3 & $\mathbf{0 , 7 9 7 6}$ & 0,3888 & 0,5482 & 0,2881 \\
MM4 & $\mathbf{0 , 7 5 0 7}$ & 0,3970 & 0,3638 & 0,1948 \\
MM 5 & $\mathbf{0 , 8 1 4 2}$ & 0,5797 & 0,2503 & 0,2232 \\
MM 6 & $\mathbf{0 , 8 2 4 1}$ & 0,5587 & 0,2654 & 0,1890 \\
MM 7 & $\mathbf{0 , 8 5 1 2}$ & 0,3852 & 0,3973 & 0,2027 \\
CT1 & 0,5743 & $\mathbf{0 , 9 3 5 2}$ & 0,5363 & 0,5189 \\
CT2 & 0,5037 & $\mathbf{0 , 9 1 2 4}$ & 0,4563 & 0,4290 \\
PD1 & 0,4111 & 0,4534 & $\mathbf{0 , 8 9 4 4}$ & 0,4926 \\
PD2 & 0,3772 & 0,4981 & $\mathbf{0 , 9 1 8 4}$ & 0,6195 \\
PD3 & 0,4441 & 0,4978 & $\mathbf{0 , 8 8 5 0}$ & 0,7537 \\
CS1 & 0,2767 & 0,4737 & 0,6681 & $\mathbf{0 , 9 4 9 8}$ \\
CS2 & 0,3103 & 0,5069 & 0,6735 & $\mathbf{0 , 9 5 0 5}$ \\
\hline
\end{tabular}

aBold values are loadings for indicator, which are above the recommended value of 0.5 .

bLoading and cross-loading criterion: An indicator's loadings on its own construct are in all cases higher than all of its cross-loadings with other constructs.

${ }^{c} M M=$ Marketing Mix; $C T=$ Customer Trust; $P D=$ Purchase Decision; $C S=$ Customer Satisfaction; $B I=$ Behavioral Intention.

${ }^{\mathrm{d} M M 1}$ = Product; $M M 2$ = Price; MM3 = Promotion; MM4 = Place; MM5 = Process; MM6 = People; MM7 = Physical Evidence; CT1 = Trust Belief; $C T 2=$ Trust Intention; $P D 1=$ Information Search; $P D 2=$ Evaluation; $P D 3=$ Actual Purchase $;$ CS1 = Excpectation; $C S 2$ = Overall Satisfaction .

\section{Structural Model:}

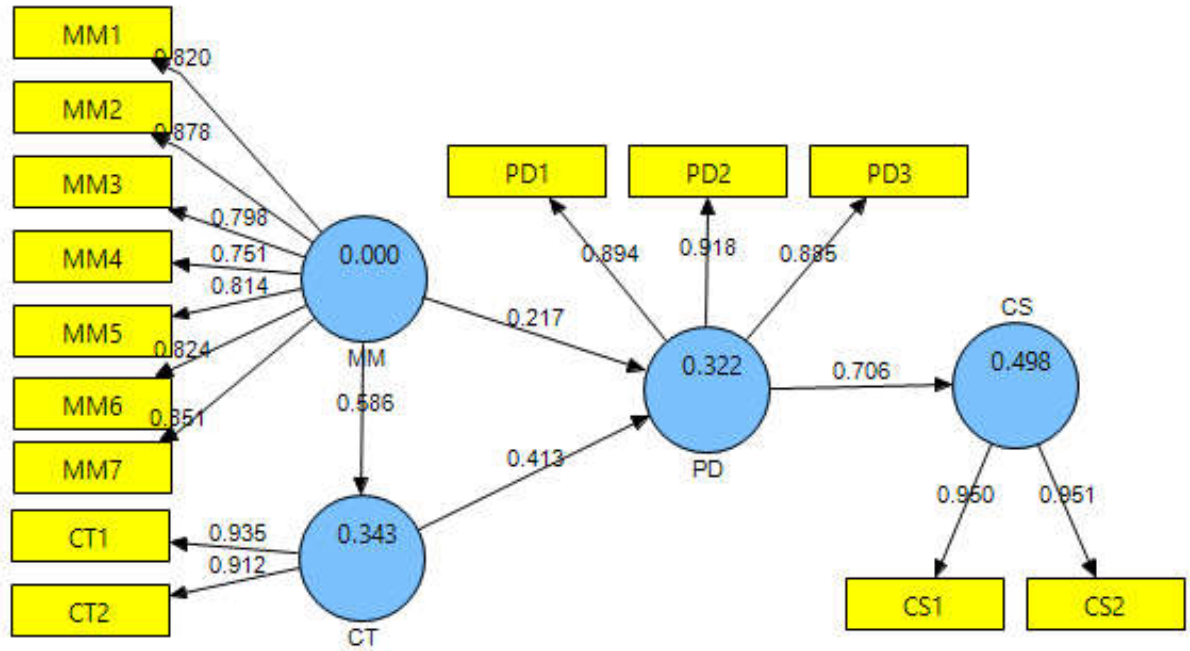

Figure 3 - Measurement model (Outer loadings, path coefficient, and $\mathrm{R}^{2}$ )

aMM = Marketing Mix; $C T=$ Customer Trust; $P D=$ Purchase Decision; $C S$ = Customer Satisfaction; $B I=$ Behavioral Intention

${ }^{b}$ MM1 = Product; $M M 2$ = Price; MM3 = Promotion; MM4 = Place; $M M 5$ = Process; MM6 = People; MM7 = Physical Evidence; CT1 = Trust Belief; CT2 = Trust Intention; PD1 = Information Search; $P D 2=$ Evaluation; $P D 3=$ Actual Purchase $;$ CS1 = Excpectation; $C S 2=$ Overall Satisfaction .

Once the measurement model was assessed and the constructs validated, the next step was the assessment of the structural model and their causal relationships. The researchers assessed the structural model of the reflective constructs following the steps and procedures proposed by Hair and et al (2013). First, the structural model for collinearity was assessed. This step was undertaken to ensure that there are no biased $\beta$, the estimations of which might involve significant levels of collinearity among the exogenous constructs. Using 
the SPSS linear regression option, the analysis shows that all VIF values were well below the threshold of 5.00, thereby demonstrating that multicollinearity is not an issue in this study. Second, the significance and relevance of the structural model relationships were evaluated using the PLS algorithm option. In addition to the structural relationships, researchers examined the significance of the relationship by performing the bootstrapping option of 5000 resamples. Table 5 depicts the $\beta$, which represents the hypothesized relationships between the constructs and their level of significance (t statistics).

Table 5 - Path Coefficient

\begin{tabular}{llllll}
\hline Hypothesis & Path $^{b}$ & Path Coefficent $(\beta)$ & Standard Error & $T$ Statisticsa $^{\text {D }}$ & Decision \\
\hline H1 & MM $\rightarrow$ CT & 0,5857 & 0.017816 & $7.0565^{* * *}$ & Supported \\
H2 & MM $\rightarrow$ PD & 0,2172 & 0.017652 & $2.2709^{*}$ & Supported \\
H3 & CT $\rightarrow$ PD & 0,4127 & 0.020590 & $3.4566^{* * *}$ & Supported \\
H4 & PD $\rightarrow$ CS & 0,706 & 0.010054 & $14.9694^{* * *}$ & Supported \\
\hline
\end{tabular}

at values for one-tailed test: ${ }^{*} 1.645$ (sig. level 0.05), ${ }^{* *} 2.326$ (sig. level $\left.=0.01\right)$, and ${ }^{* *} t$ value $2.576($ sig. level $=$ 0.005).

${ }^{b} M M=$ Marketing Mix; $C T=$ Customer Trust $; P D=$ Purchase Decision $; C S=$ Customer Satisfaction .

As depicted in Table 5, Hypothesis 1 stated that marketing mix (MM) had a significant, positive effect on customer trust (CT) with a path coefficient of 0.5857 and t-statistic of 7.0565 , which was greater than the t-table $(1.645)$ or $p \leq 0.05$. This indicated that the better the marketing mix applied by a company, the higher the customer trust. This research also demonstrated that marketing mix attributes product, price, place, people, promotion, process, and physical evidence served as factors that influenced customer trust. This research's results were in line with those of research conducted by Kim et al. (2014) and Hikmawati et al. (2015), which stated that marketing mix has a significant effect on customer trust.

Hypothesis 2 stated that marketing mix (MM) has a significant, positive effect on purchase decision (PD) with a path coefficient of 0.217 and t-statistic of 1.437, which was greater than the t-table (1.645) and was significant or had $p \leq 0.05$. These statistical results indicated that the better the marketing mix applied by a company, the better the purchase decision. This research's results were supported by the results of previous studies, which stated that marketing mix has a significant effect on purchase decision (Hidayati, 2016 and Kusumawati, 2014).

Hypothesis 3 stated that customer trust (CT) has a significant, positive effecton purchase decision (PD). The statistical results demonstrated a path coefficient of 0.3778 and $\mathrm{t}$-statistic of 2.418 , which was greater than the t-table value (1.645) and had $p \leq 0.05$. These results indicated that the greater the customer trust is, the less the customers were hesitant to purchase or use the services provided by Excellent Translation. This was in line with the argument of Pavlou and Gefen (2004) that customer trust is a requirement for the success of e-commerce as customers will not make a purchase unless they trust the seller. The results of this research were supported by previous studies, which stated that customer trust has a significant effect on purchase decision (Prabowo et al., 2014 and Beccera, 2009).

Hypothesis 4 stated that purchase decision (PD) has a significant, positive effect on customer satisfaction (CS). This was based on the results of the statistical analysis, which indicated a path coefficient of 0.706 and t-statitic of 11.6438, which was greater than the $t$ table (1.645) and was significant or had $p \leq 0.05$. These results indicated that the better the purchase decision, the greater the customer satisfaction. This was in line with the opinion of Isliko (2010), who stated that purchase decision is the foundation of the creation of customer satisfaction. Purchase decision of prime quality considerably determines how usage and usefulness can bring customers satisfaction. Strong purchase intention may indicate how much usefulness and satisfaction customers may receive.

The level of the $R^{2}$ values was assessed as another step in evaluating the structural model. The R2 values of the endogenous latent variables are obtained from the PLS algorithm option. According to Hair et al (2011), an $\mathrm{R}^{2}$ value for the endogenous latent variable of 0.75 is described as substantial, 0.50 is described as moderate, and 0.25 is 
considered as weak. Table 6 indicated that the R-square value of variable customer trust was 0.3431 . The R-square value indicated that $34.31 \%$ of variable customer trust (CT) could be influenced by variable marketing mix (MM), while the remaining $65.69 \%$ could be influenced by variables that were not examined in this research. The square value of purchase decision was 0.3225, which indicated that purchase decision (PD) was influenced by marketing mix (MM) and customer trust (CT) at $32.25 \%$, while the remaining $67.75 \%$ was influenced by variables that were not examined in this research. The R-square value for variable customer satisfaction (CS) was 0.4984 , which indicated that $49.84 \%$ of variable customer satisfaction was influenced by purchase decision (PD), while the remaining $50.16 \%$ was influenced by variables that were not examined in this research. The R-square value of variable behavioural intention (BI) was 0.676 , which indicated that $67.6 \%$ of variable behavioural intention $(\mathrm{BI})$ was influenced by customer satisfaction (CS), while the remaining $32.4 \%$ was influenced by variables that were not examined in this research

Table 6 - R-Square Values

\begin{tabular}{llll}
\hline Endogenous latent constructs & $R^{2}$ & $Q^{2}$ & Effect Size $^{\mathrm{a}}$ \\
\hline CT & 0.3431 & 0.3431 & Large \\
PD & 0.3225 & 0.3225 & Large \\
CS & 0.4984 & 0.4984 & Large \\
\hline
\end{tabular}

aAssessing predictive relevance or effect size (Q2): Value effect size: $0.02=$ Small; $0.15=$ Medium; $0.35=$ Large. ${ }^{b} \mathrm{CT}=$ Customer Trust; $P D=$ Purchase Decision; $C S=$ Customer Satisfaction.

The PLS model evaluation was carried out using $Q^{2}$ predictive relevance to measure how good the observation value resulted by the model and the parameter estimation. But, $\mathrm{Q}^{2}$ predictive relevance can not be calculated with the formula if there is only one independent variable. Thus, the value of $Q^{2}$ will be equal to the value of $R^{2}$ of the dependent variables (Latan \& Noonan, 2017).

\section{CONCLUSION}

Given that the focus of this research was to figure out the correlations between marketing mix, trust, purchase decision, customer satisfaction and the research object was the experience of online customers in using the services provided by Excellent Translation, the customer behaviour since before making purchase decision, during the making of purchase decision, until the service was used was measured using the indicators making up the variables.

Marketing mix is a marketing attribute that a company can control to influence customers in addition to customers' environment and internal motivation. In optimizing the attribute, the company needs research on their market target to identify their customers' perception. This research adopted the marketing mix that had been adjusted to e-commerce companies. In other words, some attributes were adjusted to the condition of the company. As a result, marketing mix significantly affected customer trust. Customer trust was established due to the attributes of the marketing mix applied by the company, for example the product type, the product price, the promotion conducted by the company, the website management routine, the employee competence, the services provision process, and the website appearance quality. Meanwhile, purchase decision is made after customers evaluate and choose which product or service has greater advantage. In other words, purchase decision is made after customers evaluate and choose the marketing mix applied by a company. Thus, it can be concluded that marketing mix has a significant effect on purchase decision. Based on the results of this research, it can be seen in table 2 indicator MM2 or price has value of $\mathrm{t}$-count and outer weight bigger than indicator of marketing mix other ( $\mathrm{t}$ statistc $=27.740571$; Outer Weight $=0.877719)$, this means strategy of determination of price must be more reckoned considering the price indicator gives the most influence when a company has decided to maximize purchasing decision and trust, although overall the attribute of marketing mix by Excellent Translation can influence the target market. 
Customer trust had a significant effect on purchase decision. In other words, high customer trust increases customer purchase intention. This means that purchase decision is made after customers gain trust, given that customer trust occurs after customers are stimulated by the marketing mix applied by the company. It can be concluded that marketing mix indirectly affects purchase decision through customer trust. It can be seen in table 5 customer trust significantly affect the purchase decision (t-statistc $=3.4566 ; \beta=0,4127$ ). This means Excellent Translation has gained consumer confidence so that, consumers decide to use their services. Customers believed that Excellent Translation would meet their need consistent with the offer (trusting belief), and they could submit their personal data and confidential documents to be translated without any sense of worry (trusting intention).

The results of this research indicated that purchase decision had a significant effect on customer satisfaction. In other words, strong purchase decision indicates fulfilled expectation. As for a service company, customers make decision right when they receive the service, and they will judge whether their expectation is fulfiled or not. Once the entire process of service provision is completed, customers will make overall judgment (overall satisfaction). Based on this researach, what customers expected was consistent with the offer, and the customers were satisfied with the service provided by Excellent Translation. From this satisfaction which further determines the consumer behavior in the future, whether they will change to another competitor or stay loyally and keep purchasing.

\section{RESEARCH LIMITATION}

This research had some limitation and attention should be paid to the results although procedural and statistical methods were used to overcome bias. Sample was taken from an e-commerce-based translation service providing company within a limited period of time, which possibly would yield different results if this research was conducted in a different company within different period of time. Therefore, further research in another e-commercebased company engaged in a different sector is advised. The independent variable used in this research was only marketing mix, while in fact, customer behaviour in making a purchase decision is not only influenced by marketing mix, although it has a general coverage of marketing elements. For more details, further research is expected to add some new variables. For example, in the technological sector, there are some other variables such as e-servquality, transaction security, information quality, web design, and entertainment. Meanwhile, in the social sector, demographic information such as culture, social capability, ethnic group, etc. can be added. It is expected that future research can make greater contribution in the science of marketing and behaviour of customers, especially netizen.

\section{REFERENCES}

1. Anderson, J. C., \& Gerbing. (1982). Some methods for respecifying measurement models to obtain unidimensional construct measurement. Journal of Marketing Research, 19, $453-460$.

2. Anderson, R.E., \& Srinivasan, S.S. (2003). E-satisfaction and E-loyality: a Contingency framework. Pyschology \& Marketing, 20(2), $123-138$.

3. Bagozzi, R. P., Y. Yi., \& Phillips. (1991). Assessing construct validity in organizational research. Administrative Science Quarterly, 36(3), 421- 458.

4. Bagozzi, R.P., \& Gopinath. (1999). The Role of Emotions in Marketing. Journal of the Academy of Marketing Science, 27(2), 184-206.

5. Becerra, E.P., \& Korgankar. (2009). Effects of trust beliefs on customers' online intentions. European Journal of Marketing, 45(6), 936 - 962.

6. Booms, B.H., \& Bitner, M.J. (1981). Marketing Strategies and Organization Structures For Service Firms. Chicago: American Marketing Association.

7. Chen, Y., \& Barnes, S. (2007). Initial Trust amd Online Buyer behaviour. Industrial Management and Data Systems, 107(1), $22-36$. 
8. Engel, J. F., Black., \& Miniard. (1993) Customer Behaviour (7th Ed). New York:The Dryden Press.

9. Fornell, C., \& Larcker. (1981). Evaluating structural equation models with unobservable variables and measurement error. Journal of Marketing Research, 18(1), 39-50.

10. Gefen, D. (2000). E-Commerce: the role of familiarty and trust. The International Journal of Management Science, 28(6), 725 - 737.

11. Gerson, R. (1993). Measuring Customer Satisfaction. Mississauga: Crisp learning.

12. Ghozali, I. (2006). Aplikasi Analisis Multi variate Dengan Program SPSS. Semarang: Badan Penerbit Universitas Diponegoro.

13. Hafeez, S., \& Hasnu. (2010). Customer Satisfaction for Cellular Phonesin Pakistan: A Case Study of Mobilink. Business and Economics Research Journal, 1(3), 35-44.

14. Hair, J. F., Ringle., \& Sarstedt. (2011). PLS-SEM: Indeed a silver bullet. Journal of Marketing Theory and Practice, 19(2), 139-152.

15. Hair, J. F., et al. (2013). A Primer on Partial Least Squares Structural Equation Modeling (PLS-SEM). Thousand Oaks, CA: Sage Publications.

16. Henseler, J., \& Fassott, G. (2010). Testing Moderating Effects In PLS Path Models: An Illustration Of Available Procedures. Berlin: Springer.

17. Hidayati, E. (2016). Study Of Marketing Mix And Aida Model To Purchasing On Lineproduct In Indonesia. European Centre for Research Training and Development UK, $4(7), 49-62$.

18. Hikmawati, N.K., \& Sucherly, S. S. (2015). Influence of Marketing Relations And Marketing Mix On Customers Trust On Mobile Service Operators In Indonesia. International Journal of Economics, Commerce and Management, 3(11), 410 - 422.

19. Isliko, T. W. A., \& Mintarti, R. (2010). Mediasi Keputusan Pembelian pada Pengaruh Faktor Situasional dan Faktor Produk terhadap Kepuasan Konsumen Supermarket di Kota Kupang. Jurnal Aplikasi Manajemen, 8(2), 480 - 492.

20. Jarvenpaa, S.L., Noam, T., \& Michael, V. (2000). Customer Trust in an Internet Store. Information Technology and Management, 1, 45 - 71.

21. Johnson, M. D., Anderson, E. W., \& Fornell, C. (1995). Rational and adaptive performance expectations in a customer satisfaction framework [Electronic version]. Journal of Customer Research, 21(4), 695-707.

22. Kalyanam, K., \& Mclntyre, S.(2002). The E-Marketing Mix: A Contribution of the E-Tailing Wars. Journal of the Academy of Marketing Science, 30(4), 487-499.

23. Kautsar, A. P., Sunu, W., Rizky, A., \& Hesti, A. (2012). Relationship of Customer Involvement, Credibility of the Source of Information and Customer Satisfaction on Purchase Decision of Non-Prescription Drugs. Procedia - Social and Behavioral Sciences, 65(2012), $449-454$.

24. Keen, P., Balance., Chan \& Schrump (2000) Electronic Commerce Relationship: Trust by Design. Boston: Prentice-Hall.

25. Kementerian Komunikasi dan Informatika. (2016(. "Menkominfo: Pemerintah Dorong Pertumbuhan e-Commerce Indonesia". Retrieved from www.kominfo.go.id

26. Kim, K.P., Kim, Y.O., Lee, M.K., \& Youn, M.K. (2014). The Effects Of Co-Brand Marketing Mix Strategies On Customer Satisfaction, Trust And Loyalty For Medium And Small Traders And Manufacturers. Journal E\&M Economics and Management, 17(1), 140-151.

27. Kotler, P., \& Keller. (2012). Marketing Management. Boston: Prentice Hall

28. Kotler, P., \& Armstrong, G. (2010). Principles of Marketing. New Jersey: Pearson Education.

29. Kotlyarov, I. D. (2012). Trends in the Evolution of E-commerce. Internet Marketing, 4(70), 252-258.

30. Kusumawati, R. D., Teddy, O., Rooswhan, B., \& Vikas, K. (2014). The Influence of 7P's of Marketing Mix on Buying Intention of Music Product in Indonesia. Procedia Engineering 97( ), $1765-1771$. 
31. Latan, H., \& Richard, N. (2017). Partial Least Squares Path Modeling: Basic Concepts, Methodological Issues and Applications.Switzerland: Springer International Publishing AG.

32. Lee, J.A., \& Kacen. (2008). Cultural influence on Customer Satisfaction with Impulse and Planned Purchase Decision. Journal of Business Research, 61(3), 265 - 272.

33. Lee, M.K.O \& Turban. (2001). A Trust Model for Customer Internet Shopping. International Journal of Electronic Commerce, 6(1), 75-91.

34. Luo, X., \& Homburg, C. (2007). Neglected Outcomes of Customer Satisfaction. Journal of Marketing, 71 (2), 133-49.

35. Mattila, A.S., \& Enz. (2002). The Role of Emotions in Service Encounters. Journal of Service Research, 4(4), 268-277.

36. McKnight, D.H., Viviek, C., \& Charles, K. (2002). The impact of initial customer trust on intentionsto transact with a web site: a trust building model. Journal of Strategic Information Systems, 11( ), 297 - 323.

37. Mohr, J., Sanjit, S., \& Stanley, S. (2010). Marketing of High - Tecnology Products and Innovation. New Jersey: Pearson Education, Inc.

38. Moorman, C., Rohit, D., \& Gerald, Z. (1993). Factor Affecting Trust in Market Research Relationships. Journal of Marketing, 57(1), 81- 101.

39. Morgan, R.M., \& Hunt. (1994). The Commitment-Trust Theory of Relationship Marketing. American Marketing Association, 58(3), 20-38.

40. Mowen, J.C., \& Minor, M. (1998). Customer Behaviour. Upper Saddle River. N.J.: Prentice-Hall.

41. Nowlis, S.M. (1995). The effect of time pressure on the choice between brands that differ in quality, price, and product features. Marketing Letters, 6(4), $287-295$.

42. Oliver, R.L. (1980). A cognitive model for the antecedents and consequences of satisfaction. Journal of Marketing Research, 17(4), $460-469$.

43. Pavlou, P.A., \& Gefen. (2004). Building Effective Online Marketplaces with InstitutionBased Trust. Information Systems Research, 15(1), 37-59.

44. Peter, J. P., \& Olson, J. C. (2008). Customer Behavior and Marketing Strategy. Boston: McGraw-Hill//rwin.

45. Pinson, C., \& Jolibert, A., (1997). Customer behaviour: an overview of current approaches and issues, In European Perspectives on Consumer Behaviour, Edited by Lambkin, M, Foxall, G, Raaij F.V. \& Heilbrunn, Boston: Prentice Hall

46. Pogorelova, V., et al. (2016). Marketing Mix for E-commerce. International Journal Of Environmental \& Science Education, 11(14), 6744-6759.

47. Prabowo, H., \& Darman, E. N. (2014). Analisis Kepercayaan dalam C2C E-commerce Terhadap Keputusan Pembelian dan Dampaknya Terhadap Repurchase pada KASKUS. BINUS Business Review, 5(1), 301-314.

48. Quareshi, G. k. T. K. (2015). Factors obstructing intentions to trust and purchase products online. Asia Pacific Journal of Marketing and Logistics, 27(5), 82- 96.

49. Richins, M. L. (1997). Measuring Emotions in the Consumption Experience. Journal of Customer Research, 24(2), 127-146.

50. Ringle, C. M., Wende, \& Will. (2005). Smart PLS 2.0 M3. Hamburg: University of Hamburg.

51. Sonja, G. K., \& Ewald, A. K. (2003). Empirical research in on-line trust: a review and critical assessment. International Journal of Human-Computer Studies, 58( ), 783 - 812

52. Yunus. (2006). Building Trust. Retrieved from http://www.gsn-soeki.com/wouw. 